\title{
Summer rainstorm associated with a debris flow in the Amarilla gully affecting the international Agua Negra Pass $\left(3^{\circ} 20^{\prime} \mathrm{S}\right)$, Argentina
}

\author{
Carolina Lauro $^{1}$ (D) Stella M. Moreiras ${ }^{1,2} \cdot$ Sebastian Junquera $^{1} \cdot$ Ivan Vergara $^{1}$ \\ Rafael Toural $^{1} \cdot$ Johannes Wolf $^{3} \cdot$ Ruben $^{\text {Tutzer }}{ }^{3}$
}

Received: 22 April 2016/ Accepted: 21 February 2017

(C) Springer-Verlag Berlin Heidelberg 2017

\begin{abstract}
The Central-West region of Argentina was seriously affected by a series of convective summer storms on January-February of 2013 generating many debris flows and rockfall in the Central Andes mountain regions. In particular, the unreported 8th February event caused the sad death of a 10-year-old child being completely ignored by society and local authorities. Despite this, meteorological conditions associated with this event and further episodes were rarely measured and determined mainly due to scarce meteorological stations in Andean mountain areas. In this paper, meteorological data from CMORPH algorithm and measurements of surrounding gauges were analyzed for estimating the triggering precipitation value of
\end{abstract}

\footnotetext{
Carolina Lauro

clauro@mendoza-conicet.gob.ar

Stella M. Moreiras

moreiras@mendoza-conicet.gob.ar

Sebastian Junquera

sjunquera@mendoza-conicet.gob.ar

Ivan Vergara

ivergara@mendoza-conicet.gob.ar

Rafael Toural

rtoural@mendoza-conicet.gob.ar

Johannes Wolf

jo.wolf@gmx.at

Ruben Tutzer

ruben-tutzer@hotmail.de

1 CONICET, IANIGLA- CCT Mendoza-Argentina, Av. Ruiz Leal Parque General San Martin, 5500 Mendoza, Argentina

2 Faculty of Agriculture Sciences, National University of Cuyo, Mendoza, Argentina

3 University of Natural Resources and Life Sciences, Boku, Vienna, Austria
}

this event. As well, the particular debris flow channeled into the main branch of the Amarilla gully in the Agua Negra valley was geomorphologically described. The amount of precipitation associated with this debris flow was 5.5 and $13.2 \mathrm{~mm}$ accumulated previous to the event. This violent debris flow was generated in a talus zone in a periglacial environment located just below a covered rock glacier. However, the influence of the permafrost thawing in this process is not feasible. The altitude of the $0{ }^{\circ} \mathrm{C}$ isotherm was lower during the previous days of the event, and no monitoring on permafrost is available for this area. The volume of removed mass was estimated in $5 \times 10^{4} \mathrm{~m}^{3}$, and the mean velocity was $35 \mathrm{~km} / \mathrm{h}$. Boulders of $4 \mathrm{~m}$ diameter were found in the source area, while the deposit is up to $75 \%$ sandy with clasts that hardly exceed $10 \mathrm{~cm}$ in the alluvial fan distal part. Herein the main objective is to advice about the probable catastrophic impact of similar events in the future. These findings could be useful for hazard remediation, mitigation, and prevention plans for the Agua Negra international pass under construction.

Keywords Debris flow - CMORPH - Central Andes . Argentina

\section{Introduction}

Debris flows are defined as rapid flows of saturated nonplastic debris within a steep channel (Hungr 2005) in which a combination of loose soil, rock, organic matter, air, and water mobilize as a slurry that flow downslope (Varnes 1978; WP/WLI 1993). The source area of these events is generally associated with steep gullies, while transported material is deposited in the gentler slope of debris fans at 
the mouths of gullies. Commonly, these sudden flows are caused by intense surface-water flow as a consequence of heavy precipitation or rapid snowmelt that erode and mobilize loose soil or rock on steep slopes. This kind of movements is a common natural hazard in the Arid Central Andes triggered by intense summer rainstorms (Moreiras 2006, 2009; Esper Angillieri 2011; Marcato et al. 2012; Brea et al. 2013) being intensified during warm phases of ENSO phenomenon with precipitation above the mean (Sepúlveda et al. 2006; Moreiras 2005, 2006).

A series of convective summer storms during JanuaryFebruary of 2013 year triggered many landslides in Central Andes (Moreiras and Sepúlveda 2013; Sepúlveda et al. 2015). This type of summer storm is commonly very local affecting a specific sector of the country. However, on summer 2013 several events were registered in a huger area compressing North and Central Argentina, and Central Chile (Sepúlveda et al. 2015). As a result, many debris flows were reported in mountain areas of the Central Andes. The international road No. 7 connecting Mendoza (Argentina) with Santiago (Chile) over the Andes at $32^{\circ} \mathrm{S}$ remained closed for 10 days. Consequently, many persons were isolated, several mountain facilities collapsed, and there were severe problems in the supply of potable water in both capital cities where more than 3.5 million persons live (Moreiras and Sepúlveda 2013).

Likewise, dangerous debris flows and flashflood occurred in eastern Andes piedmont where main cities are located. At the latitude of the study area $\left(30^{\circ} \mathrm{S}\right)$, many crops and vineyards covering 6000 hectares were flooded in the department of Sarmiento, San Juan province. A flashflood channeled into the Flecha gully discharged one million of cubic meters reaching $126 \mathrm{~m}^{3} / \mathrm{s}$. This streamflow tripled the actual mean stream of the main regional permanent river in this province (San Juan River). Besides, at same latitude rainfalls caused strong mudslides on the other side of the Andes at Junta del Toro locality, Chile. Many of these events were reported, but others were completely unnoticed. This fact underestimates the real impact of such events in isolated and remote mountain areas. Such is the case of a debris flow registered on February 8, 2013, in the locality known as Arenales along the Agua Negra international road $\left(30^{\circ} 20^{\prime} \mathrm{S}\right)$ that reached an unexpected impact when caused the sad death of a 10-year-old child. The vehicle that transported the kid lost control when the driver was overpassing the muddy moving mass material disrupting the Agua Negra international pass. Despite this fatality, the event has not been reported and was ignored by local authorities. Moreover, this event caused six consecutive closing days of the international traffic that strands isolated 11 families on the Chilean customs.

The aim of this research was to establish triggering mechanism/s of this event by analyzing air temperature records and estimating the precipitation values for the 8th February ( $8 \mathrm{~F}$ in advance) event. A high-resolution satellite analysis (CMORPH) was conducted due to the lack of gauges in Andes mountain areas. In this region, precipitation records are scarce, and as a consequence, threshold values are hardly determined (Moreiras 2006). Besides, in this paper, geomorphological characteristics of this damaging event were described. Our findings are of great interests for road maintenance and advise the community on the probable catastrophic impact in the future as this kind of events is rarely considered when collective memories fail especially in remote areas with fortuity observers.

\section{Geographical setting of the study area}

The study area is situated in the Iglesia Department of San Juan province, Argentina, very close to the Chile border at $30^{\circ} \mathrm{S}$ latitude (Fig. 1). The access to this area is by the international road No. 150 connecting Jáchal (San Juan, Argentina) with La Serena (Coquimbo, Chile). The international road No. 150 runs along the valley of the Agua Negra River (ANR) until the international border. To western Chilean side, the Road CH40 continues along the Elqui valley arriving until the Pacific coasts (La Serena). The distance along these roads is $505 \mathrm{~km}$ being paved only $365 \mathrm{~km}$ of them. This partially consolidated corridor has been in construction for the last 4 years, and it is not finished yet. As the highest point of the road is over $4200 \mathrm{~m}$ asl, the pass is frequently closed during winter (July to September) because of snowy weather. A tunnel has been projected at the end of San Lorenzo valley to avoid this restriction. A total of 10,235 vehicles and 35,586 persons used this pass to cross the Andes during 2013 summer season. Usually, during the holiday period or long weekends, Argentinean families visit the Pacific Ocean beaches mainly located in La Serena. This tourism activity is rapidly increasing since 2000 .

The 20-km-long ANR valley is under the influence of the Arid Diagonal of South America characterized by low precipitations rates, dry air, high heliophany, and high evapotranspiration values on spring-summer period. The region is dominated by the semipermanent subtropical anticyclone which is disturbed by the presence of the Andes. The disturbance is manifested by interrupting the high-pressure system in two centers: one in the Atlantic Ocean and another on the Pacific Ocean. The Atlantic Ocean anticyclone has the maximum influence on the eastern ward of the Andes from December to February (Minetti et al. 1986), while the Pacific anticyclone influence is stronger during winter (May to August). Because of that, the area is dominated by two main clearly differentiated seasonal precipitation regimes depending on topography. In lower areas, intense summer rainfall regime 


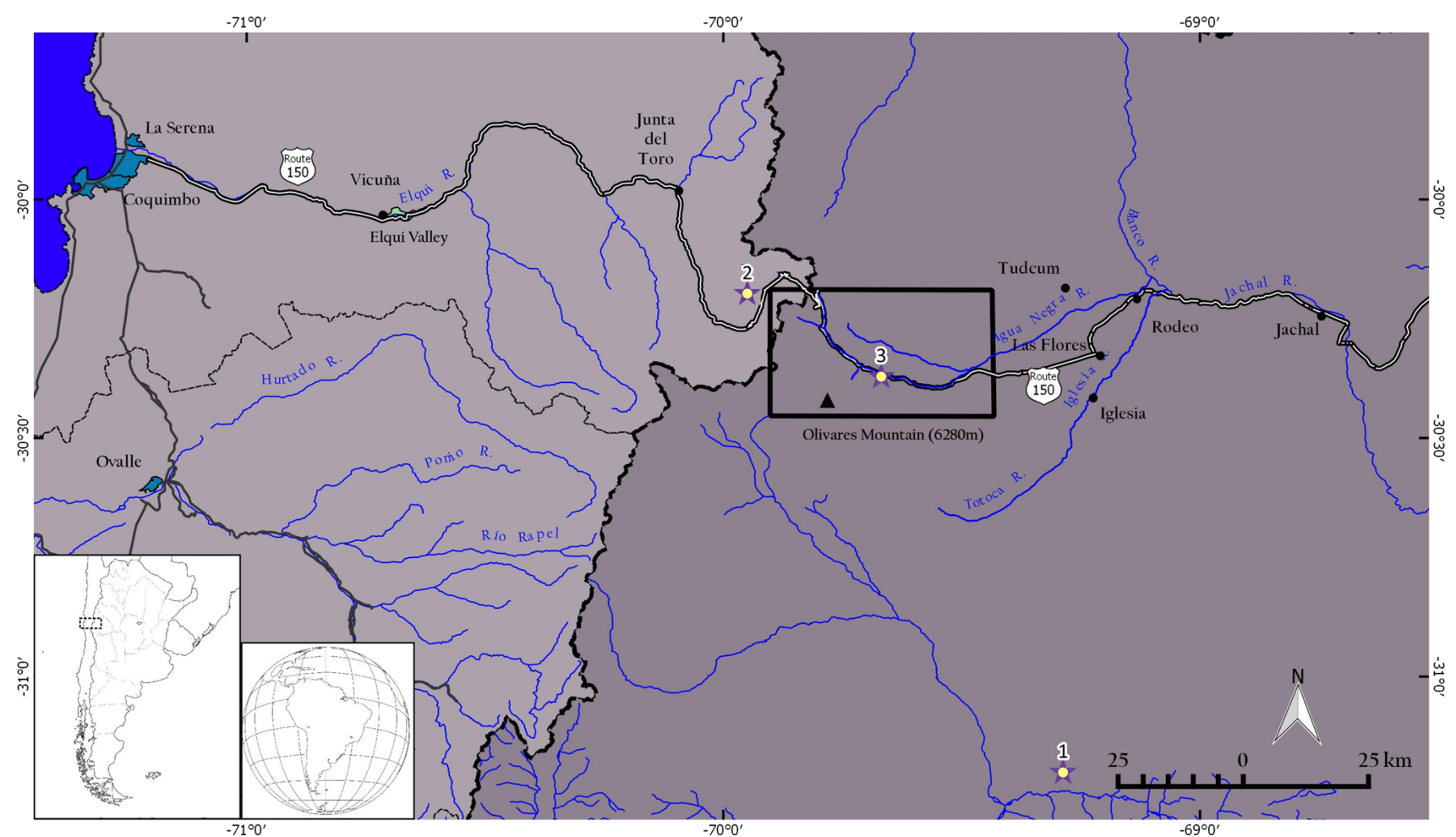

Fig. 1 Location of the study area near the border between Chile and Argentina countries. Along the Agua Negra valley, San Juan (Argentina) runs the international road 150 connecting with the Elqui valley (Road CH40), Coquimbo-La Serena (Chile). Points 1 and 2 are

predominates developed in short periods of time and with high intensity torrential forms. However, mean annual precipitation in these sectors does not exceed $100 \mathrm{~mm}$. In contrast, winter precipitations with lower frequency and intensity show longer duration comparing with summer rainfall. Mainly snowfall occurs in high topographic areas between 4000 and $6000 \mathrm{~m}$ asl in Iglesia department. Precipitations increase toward west and south reaching $300 \mathrm{~mm}$ per year in the southwest of the study area, while a minimum mean annual precipitation $(50 \mathrm{~mm})$ is recorded near Rodeo.

Geologically, the area is situated in the Frontal Cordillera geological province with west-east trench at this latitude. The basement of this geological morphotectonic unit is constituted by sedimentary rocks of Tudcum Formation and Carboniferous rocks of the Agua Negra Formation. The latter, integrated by marine pelites and sandstones (Polanski 1978), is intruded by a Permo-Triassic granite that generates local hydrothermal alterations. As well, a volcanic complex of same period regionally known as the Choiyoi Group outcrops in the area. The stratigraphic sequence follows with unconfirmed Pliocene (Doña Ana Formation) and Cenozoic volcanic rocks associated with the Olivares volcanic center (Central Olivares Mount$6280 \mathrm{~m}$ asl.) (Segemar 2000; Heredia et al. 2002) (Fig. 2). the rain gauge Km101 (Argentina) and Laguna Embalse (Chile), respectively. Point 3 shows the location precipitation taken from $\mathrm{CMORPH}$

From the geomorphological point of view, the U-shaped valley of ANR evidenced the existence of huge ice glacial masses during the Pleistocene. Uncovered cirque glaciers and covered ones are preserved at present (Leiva 1999; Milana and Maturano 1999; Croce and Milana 2002), whereas rock glaciers as a consequence of regional aridity and geoforms related to permafrost processes appear in the whole area (Schrott 1994, 1996). In particular, the Amarilla gully is located on a periglacial environment (5000-3500 m asl). The highest catchment area of this basin is occupied by two glaciers which ablated material fed the studied gully. These glaciers being part of Olivares Mount do not have a specific name, but they are related to covered rock glaciers.

Large alluvial cones developed in the main gullies draining into to ANR have been built by due to the occurrence of recurrent debris flows; still, this fact is commonly ignored.

\section{Methods}

A field campaign was carried out during November 2013 to geomorphologically study the huge damaging event occurred at the Arenales locality. During this field session, 


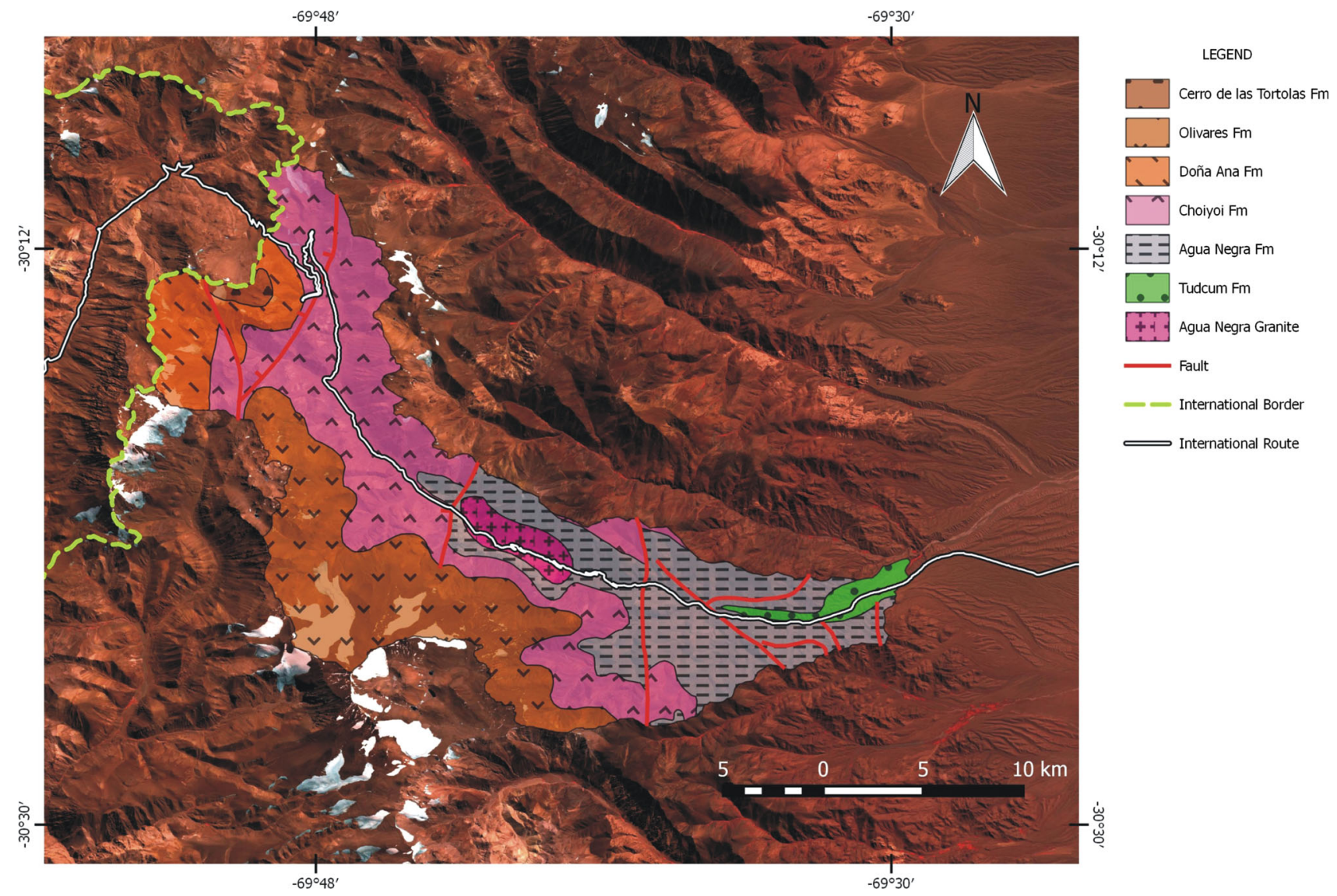

Fig. 2 Geological map showing predomination of volcanic rocks in this portion of the Frontal Cordillera geological province. The 8th February debris flow occurred in the contact of granites with Carboniferous rocks by fault

we tracked the unsorted deposit of $8 \mathrm{~F}$ debris flow along the Amarilla gully $(\mathrm{AG})$ in order to determine extension and its source area. The deposit was sedimentological described considering selection, facies, matrix content, boulder/clasts composition, maximum sizes, and shape of boulders. Three samples of deposit matrix were collected in different locations of the alluvial fan (Fig. 3). Sample 1 was taken from proximal alluvial fan area, sample 2 in the middle location of the fan, and sample 3 in a distal fan close to the road No. 150. A textural analysis was carried out to determine matrix grain size distribution $(2,1,0.5,0.25$, 0.105 , and $0.053 \mathrm{~mm}$ ) corresponding to ASTM sieves $\left(\mathrm{N}^{\circ} 10,18,35,60,140\right.$, and 270). Likewise, thickness and extension of studied deposit were measured in the field. Main morphometric parameters were estimated based on these direct measurements. Then, a friction coefficient of debris flow was established by $\mathrm{H} / \mathrm{L}$ rate. Debris flow invades lateral margins of channels especially in bends of the channel. These banked deposits were used for estimating mean velocity. The mean velocity was estimated considering: gravity acceleration $(g)$, slope angle of the channel $(\alpha)$, altitude difference between both banked deposits as lateral ridges in the cross section $(\Delta h)$, channel width in the studied section $(L)$, and curvature radius $(r)$ (Johnson and Rodine 1984).

$v=\sqrt{g \cdot \cos \cdot \alpha \cdot \operatorname{tg} \frac{\Delta h}{L} \cdot r}$

Basin features were analyzed by GIS environment using the SRTM topography. As well, direct data were recovered interviewing occasional observers working on the road construction. Although local newspapers were collected in order to find extra information, this event was completely ignored by the press and the whole society of San Juan.

Estimating precipitation threshold value for triggering landslides is not a single task (Coe et al. 2004; Guzzetti et al. 2007, 2008). Maybe the most popular hydrological model validated was developed by Iverson (2000) and further used (Crosta and Frattini 2003; Keim and Skaugset 2003; Frattini et al. 2004; Lan et al. 2005; D'Odorico et al. 2005). However, main requirements on successful values for the determination are: the distribution of gauges, 24-h recording, determination of intensity or rainfall duration 

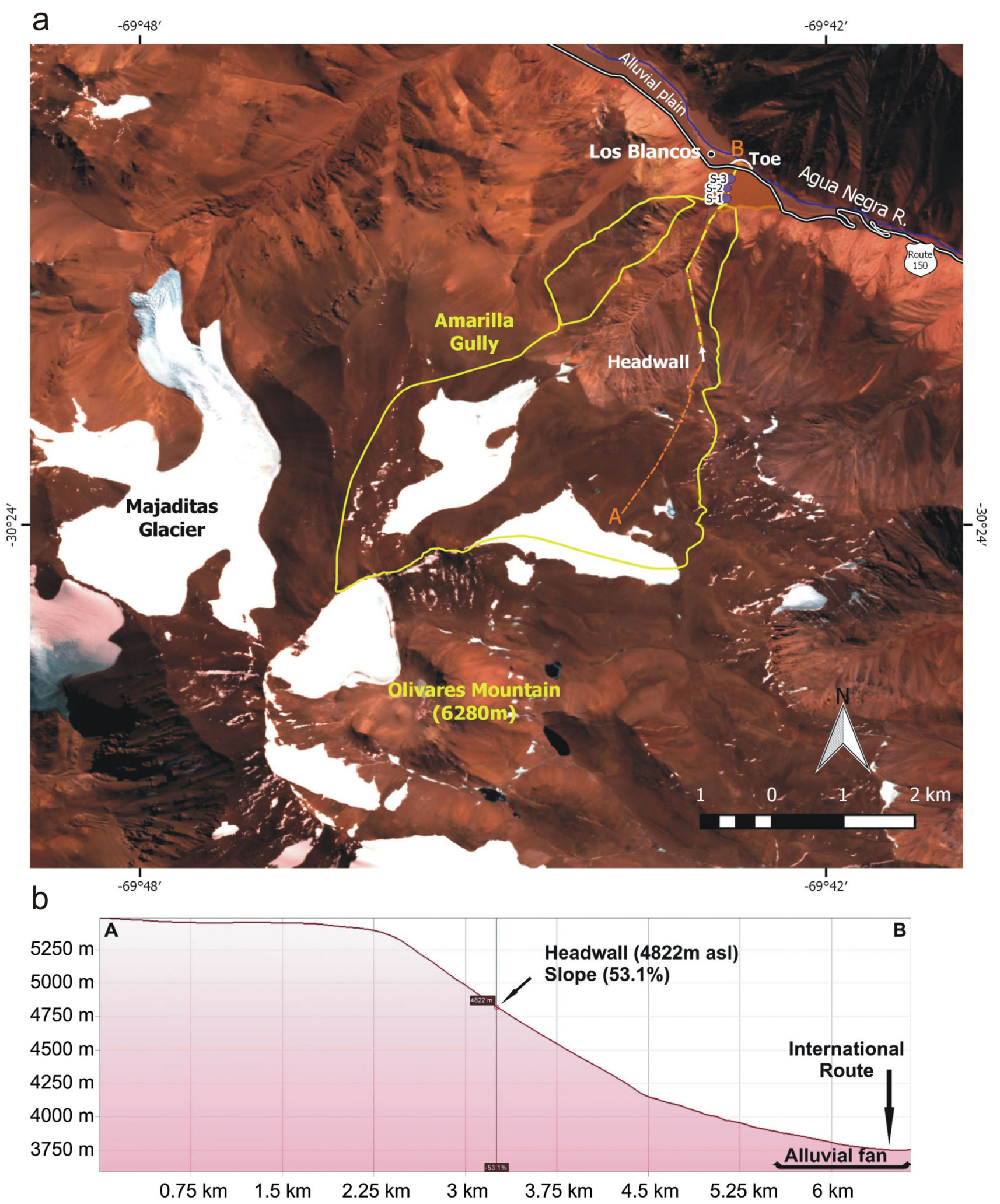

Fig. 3 a Google earth image showing the Amarilla gully basin. Uncovered glacier domains at highest altitudes. The source area of the 8th February is below this glacial area. The 8F flow was channelized along Amarilla gully invading the distal alluvial fan and flooding Arenales-Los Blancos locality in the Agua Negra valley. An alluvial plain is observed upstream of the Amarilla gully likely as a paleo-lake evidence associated with old blockage of the Agua Negra valley. Points S-1, S-2, S-3 show the location of the samples, $\mathbf{b}$ topographic profile from the cover glacier $(A)$ to the depositional area $(B)$. The headwall $(4822 \mathrm{~m}$ asl) is located $3.4 \mathrm{~km}$ far away from the distal zone (3745 $\mathrm{m}$ asl). The alluvial fan is $950 \mathrm{~m}$ in length 
and accessibility for gauges maintenance, among others (Cannon and Ellen 1985; Jibson 1989; Govi et al. 1985; Wieczorek et al. 2000). The influence of the antecedent rainfall has been also considered in the rainfall threshold for landslide occurrence in some studies (Glade 2000; Moreiras 2006). Nevertheless, estimations carried out in isolated mountain areas are harder to be processed for convective local rainfall. Scarceness of meteorological stations with poor distribution in huge areas is not enough for precipitation correlations.

Nowadays high-resolution satellite technology brings the opportunity to estimate daily precipitation in areas where rain gauges are sparse and limited (Su et al. 2008; Kjelstad 2011; Chen et al. 2013). Satellite precipitation products are very useful for hydrometeorological applications such as flood and landslide processes. In the release area of the $8 \mathrm{~F}$ debris flow, the lacking of local gauges disallowed a measurement of rain precipitation at the place. So 24-h precipitation was derived from the morphing technique (CMORPH) estimating rainfall precipitation from observations of low orbiter satellite microwave exclusively. Information is transported via spatial propagation that is entirely obtained from geostationary satellite IR data. Estimated precipitations are available on a grid with a spacing of $8 \mathrm{~km}$ (at the equator), while the resolution of the individual satellitederived estimation is lower than this value-more on the order of $12 \times 15 \mathrm{~km}$. The finer resolution is obtained via interpolation (Joyce et al. 2004). Data were downloaded from the Web site of the KNMI Climate Explore (http:// climexp.knmi.nl/selectdailyfield2.cgi?id=some one@somewher). This Web site allows obtaining a grid point, setting one latitude and one longitude, and then selecting halfway grid points.

Regarding the accuracy of CMORPH estimations, two extra datasets were compared. Two distant precipitation gauges were chosen for comparing precipitation values: Laguna Embalse (LE) located in Chile, approximately at $35 \mathrm{~km}$ toward the northwest of the study area, and Km101 gauge $(\mathrm{Km} 101)$ located at $113 \mathrm{~km}$ southeastern, in Argentinean side (Fig. 1, Table 1).

Also, CMORPH data were obtained for the two precipitation gauges (LE and Km101) and were statistically analyzed with 24 -h precipitations recorded in these gauges considering the same time period (January 1, 2011, to December 31, 2014). The correlation coefficient $(\mathrm{cc})$, bias, root-mean-squared difference (RMSD), probability of detection (POD), false alarm rate (FAR), and critical success index (CSI) were used as statistic parameters for correlation (Schaefer 1990).

$\mathrm{cc}=\operatorname{cov}(S, \mathrm{RG}) / \sigma S \sigma \mathrm{RG}$

bias $=\frac{1}{n} \sum_{i}^{n}\left(S_{i}-\mathrm{RG}_{i}\right)$

$\mathrm{RMSD}=\sqrt{\frac{1}{n} \sum_{i}^{n}\left(S_{i}-\mathrm{RG}_{i}\right)^{2}}$

$\mathrm{POD}=A /(A+C)$

$\mathrm{FAR}=B /(A+B)$

$\mathrm{CSI}=A /(A+B+C)$

where cov refers to covariance, $\sigma$ is standard deviation, $S$ is precipitation taken with CMOPRH, $R G$ is precipitation at rain gauge measurement, $A$ is the number of hits that correctly estimate rain by the algorithm, $B$ is the number of times that it rains but the algorithm shows no rain, and $C$ is the number of time that the algorithm incorrectly estimated to be rainy but rain did not occur.

The headwall of the $8 \mathrm{~F}$ event is initiated in a periglacial zone just below a covered glacier. In this cold environment associated with permafrost, debris flows could be generated by ice ablation or snow melting. In order to explore a possible influence of permafrost thawing on the studied event, the air temperature anomalies at $500 \mathrm{mb}$ were analyzed using the Reanalysis dataset of the National Center for Environmental Prediction-National Center for Atmospheric Research (NCEP-NCAR) (Kalnay et al. 1996). Also daily maximum and minimum air temperature recorded at KM101 and Laguna Embalse gauges (time period Jan 1, 2013, to Feb 8, 2013) were checked. The elevation of the $0{ }^{\circ} \mathrm{C}$ isotherm was interpolated with the geopotential height and the air temperature both at 600 and $500 \mathrm{mb}$ geopotential.

Table 1 Location of precipitation gauges and debris flow coordinates used for CMRPH

\begin{tabular}{lllll}
\hline Rain gauge & Altitude $(\mathrm{m}$ asl) & Latitude $\mathrm{S}$ & Longitude W & Database source \\
\hline Km101 & 1310 & 31.20 & 69.28 & Secretaria Recursos hídricos-Argentina \\
Laguna Embalse & 3160 & 30.20 & 70.04 & Dirección General de Aguas-Chile \\
Coordinates at debris flow point & 4200 & 30.37 & 69.66 & CMORPH \\
\hline
\end{tabular}




\section{The Amarilla gully basin}

The Amarilla gully (AG) basin is eroded in the northern face of Olivares Central Mount (6280 m asl), known as well as Majaditas peak. This studied basin covers a total extension of $21 \mathrm{~km}^{2}$ being elongated in E-NE strike with maximum long in this direction of $8.50 \mathrm{~km}$. It comprises two types of lithology: outcroppings of granites are in contact with Carboniferous sedimentary rocks. The main streamflow of the AG was eroded following this structural contact by the presence of a regional fault. Topography greatly contrasts along this basin with areas above $6000 \mathrm{~m}$ asl, while the most distal lower point-near the ANR valley-is $3750 \mathrm{~m}$ asl. The higher opened area of this AG basin constitutes a plateau where an uncovered glacier and a huge covered glacier with a terminal thermokarst facies appear above $5300 \mathrm{~m}$ asl. Then, upper basin of the AG is conditioned by permafrost processes favoring the generation of great amounts of unconsolidated clasts caused by cryogenic processes.

The AG shows a steep relief with a mean slope of 26.8\%; however, this basin could be divided into two areas according to slope inclination. The upper part of the basin has a relatively gentle slope (15\%) modeled by glaciers, whereas lower steep area performs a mean slope $33.6 \%$. Downstream, near the ANR valley, in the alluvial fan domain, a secondary slightly steeper branch (slope 36.3\%) fed the system coming from a smaller area $\left(1.7 \mathrm{~km}^{2}\right)$. When the confined AG valley arrives at the opened U-shaped Agua Negra valley, it builds a large alluvial fan surface integrated by alluvial and debris flow deposits. This alluvial fan covers a surface of $0.5 \mathrm{~km}^{2}$ showing very active debris flow tracks associated with previous, maybe historical, channeled events (Fig. 3). These events have produced the prehistorical/historical progressive migration of the ANR toward the north. The sudden arrival of debris material should have dammed this valley in the past evidenced by an extensive alluvial plain upstream of the AG mouth. Still, lacustrine deposits of this/these ancient obstruction(s) had not been found yet.

\section{8th February debris flow occurrence}

The debris flow occurred on February 8, 2013, was triggered by a summer rainfall, which magnitude determination is the aim of this paper. This violent event was generated in a talus zone associated with active rockfall located upstream just above a covered glacier of Olivares Central system. The water-saturated material mobilized downstream channeled into the main branch of the AG basin. Debris material ran $3.4 \mathrm{~km}$ from the source area until it reached the ANR at the latitude of Arenales/Los Blancos locality (Fig. 4a). This turbulent flow razed big boulders that reached $4 \mathrm{~m}$ in diameter (Fig. $4 \mathrm{~b}$ ). The flow topographically descended $1077 \mathrm{~m}$ with a low friction coefficient $(0.316)$. The mean velocity of this flow has been established in $35 \mathrm{~km} / \mathrm{h}$.

The material mobilized by the $8 \mathrm{~F}$ event was estimated in $5 \times 10^{4} \mathrm{~m}^{3}$ in volume. Starting time of debris flow mobilization is uncertain, but it arrived at Arenales locality at 10:00 am covering $2 \mathrm{~km}$ long of the international pass. Debris flow was preserved by many relict deposits along the main branch of the AG. Features of these deposits change according to their topographic position. Chaotic deposits reach up to $6 \mathrm{~m}$ in thickness in upper areas along AG (Fig. 4c), $<0.5 \mathrm{~m}$ in middle positions, whereas muddy deposit thickness reaches $0.1 \mathrm{~m}$ in the distal part (Fig. 4e). As well, a marked lateral variation exists in maximum block sizes. The biggest boulders were observed near the source area with a diameter of $4 \mathrm{~m}$ even blocks of $1 \mathrm{~m}$ diameter predominate. In the middle section of the branch, blocks practically disappear; still, some blocks of $0.5 \mathrm{~cm}$ in size could be observed, whereas the deposit is up to $75 \%$ sandy with clasts that hardly exceed $10 \mathrm{~cm}$ (An axial plane) in the alluvial fan distal part. Grain size distribution in samples collected from this distal part shows a predominance of medium sand fraction and low silt-clay content not exceeding 19\% (Fig. 5). Debris flow deposits show an uncommon monolithic composition constituted by granite boulders and clasts in a finer matrix integrated by participles of weathered granite. Fine sandstone clasts gray/ black in color coming from Carboniferous rock outcroppings was rarely observed.

\section{Characterization of triggering rainfall}

The $8 \mathrm{~F}$ debris flow was generated in the eastern mountain side of Central Olivares Mount (6280 m asl) after a strong summer rainfall affecting the Central-West part of Argentina. As was mentioned before, several debris flows and rock fall were documented in Argentinean and Chilean Central Andes (Moreiras and Sepúlveda 2013; Sepúlveda et al. 2015). However, local precipitation records are uncertain due to lacking on local gauges, so estimation was done by statistics comparison between precipitation data recorded in closer gauges and satellite data obtained from CMORPH (Table 2).

The correlation coefficient between CMORPH estimation and precipitation records from the $\mathrm{Km} 101$ gauge is better than the obtained for the Laguna Embalse gauge. Probably, it could be explained by the topography of the region. Laguna Embalse (LE) gauge is located in a deep valley surrounded by mountains with peaks over the $4000 \mathrm{~m}$ asl, and it is well known that CMORPH algorithm is affected by the topography (Hirpa et al. 2010). Besides, CMORPH overestimates rainfall at LE in $90 \%$ and also has 

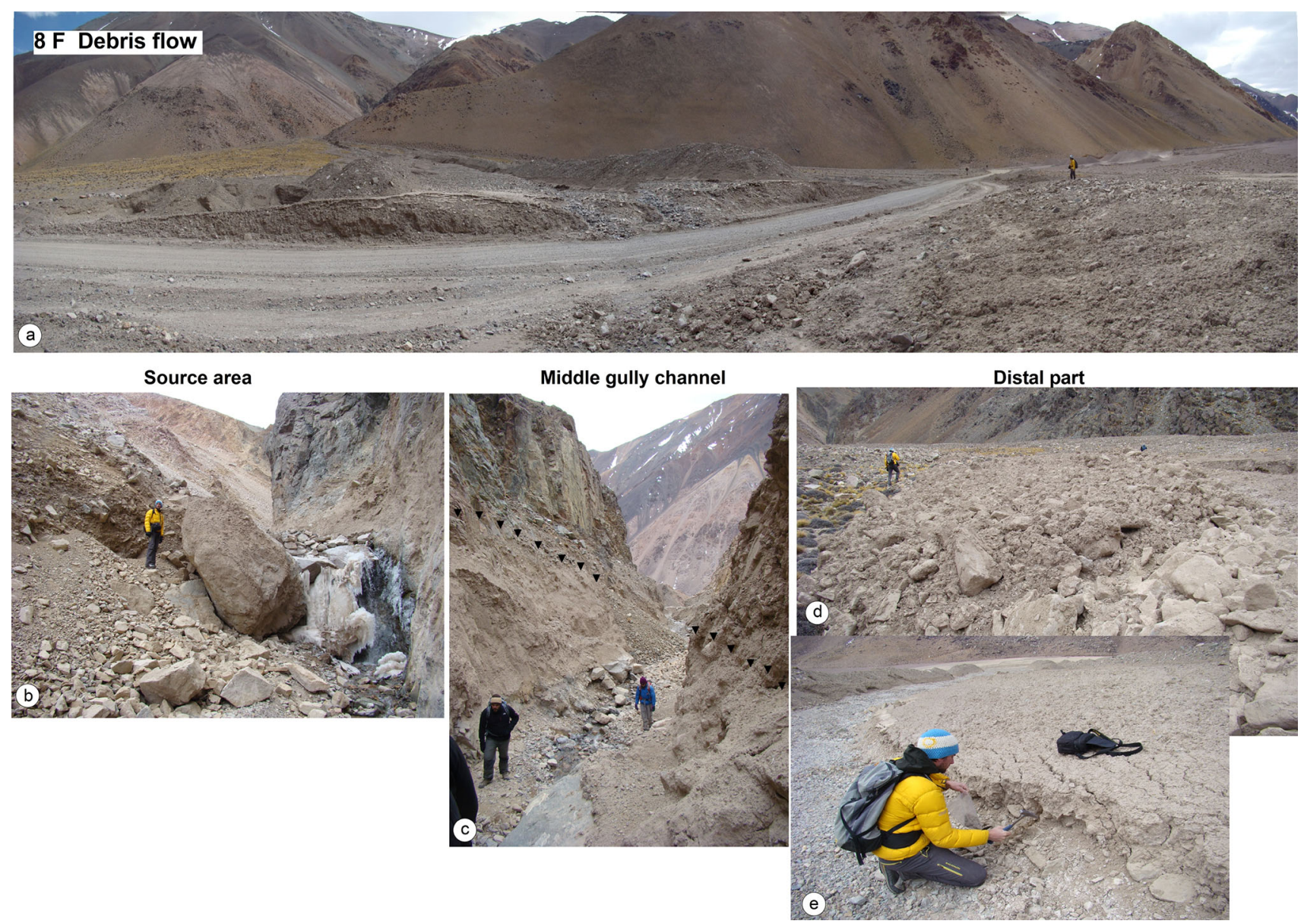

Fig. 4 Pictures of debris flow occurred on February 8, 2013: a debris material removed from the international road No. 150, where alluvial fan coming from Amarilla gully is observed, b maximum blocks size found close to source area (J. Wolf as scale reference), $\mathbf{c}$ fine deposits preserved at both margins of a narrow channel of Amarilla gully (R.

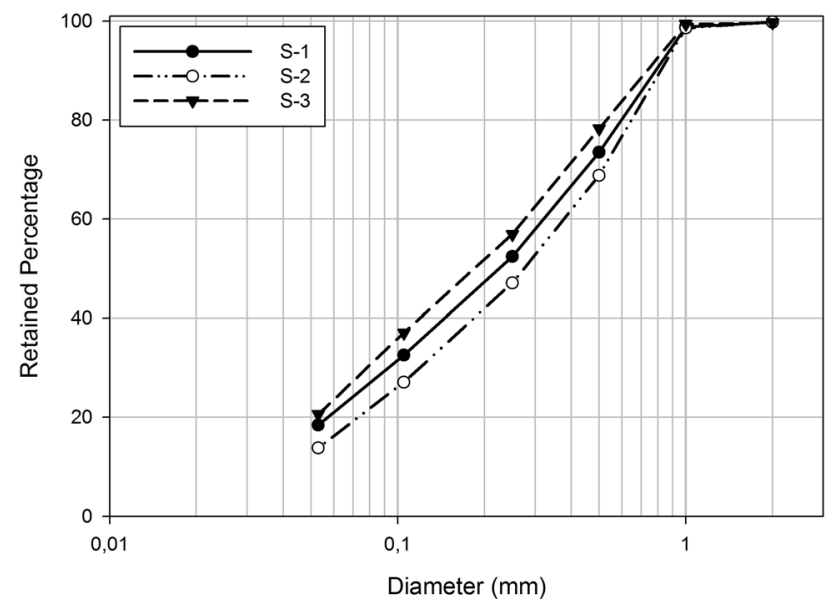

Fig. 5 Grain size distribution of the samples taken from matrix material of 8th February debris flow deposit. The three samples show a predominance of medium sand fraction. Graphs shows retained percentage of different participle diameters corresponding to number of used sieves $2 \mathrm{~mm}$ (N10), $1 \mathrm{~mm}$ (N18), $0.5 \mathrm{~mm}$ (N35), $0.250 \mathrm{~mm}$ (N60), $0.105 \mathrm{~mm}(\mathrm{~N} 140)$, and $0.053 \mathrm{~mm}(\mathrm{~N} 270)$
Toural and C. Lauro as scale reference), $\mathbf{d}$ granite boulders preserver in a levee in the medium facie of the alluvial fan, and e finer deposit on the distal parts affected by desiccation cracks (J. Wolf as scale reference)

higher RSMD comparing to correlation done for the Km101 gauge. Other parameters to evaluate the accuracy of CMORPH are POD, FAR, and CSI. POD value should be 1 , FAR should be equal to 0 , and CSI should be 1 in the ideal case of a perfect algorithm. In our case, the algorithm estimated precipitation when occurred, but also, there is a high probability that the algorithm showed precipitation when it did not occur.

The monthly distribution of precipitation showed differences in precipitation regime among the two analyzed gauges. But according to the location of study area, the monthly distribution of CMORPH estimation seems to be more similar to values recorded at $\mathrm{Km} 101$ than those recorded in the $\mathrm{LE}$ gauge (Fig. 6a). Moreover, maximum precipitation is recorded during fall and winter seasons (April to August) at LE gauge while for CMORPH DF and at the Km101 gauge are in summer time (December to February).

Low precipitation amount was estimated for the AG basin by CMORPH $(5.5 \mathrm{~mm}$ ) (Fig. 6b), so antecedent 
Table 2 Correlation between precipitation data of local rain gauges (Km101 and Laguna Embalse) with CMORPH satellite estimation

\begin{tabular}{lllllll}
\hline Rain gauge & Correlation coefficient & Bias & RSMD & POD & FAR & CSI \\
\hline Km101 & 0.27 & 0.3 & 1.9 & 0.9 & 0.8 & 0.2 \\
Laguna Embalse & 0.05 & 0.9 & 3 & 0.7 & 1 & 0 \\
\hline
\end{tabular}

$R M S D$ root-mean-squared difference, $P O D$ probability of detection, FAR false alarm rate, $C S I$ critical success index

Fig. 6 a Monthly precipitation recorded in the $\mathrm{Km} 101$ and Laguna Embalse rain gauges and estimation of rain with CMORPH model. The annual distribution of precipitation at $\mathrm{Km} 101$ is similar to CMORPH estimation. b Daily (left) and accumulated (right) precipitation with CMORPH estimation for the Amarilla gully during February 2013. The peak precipitation was on February 7
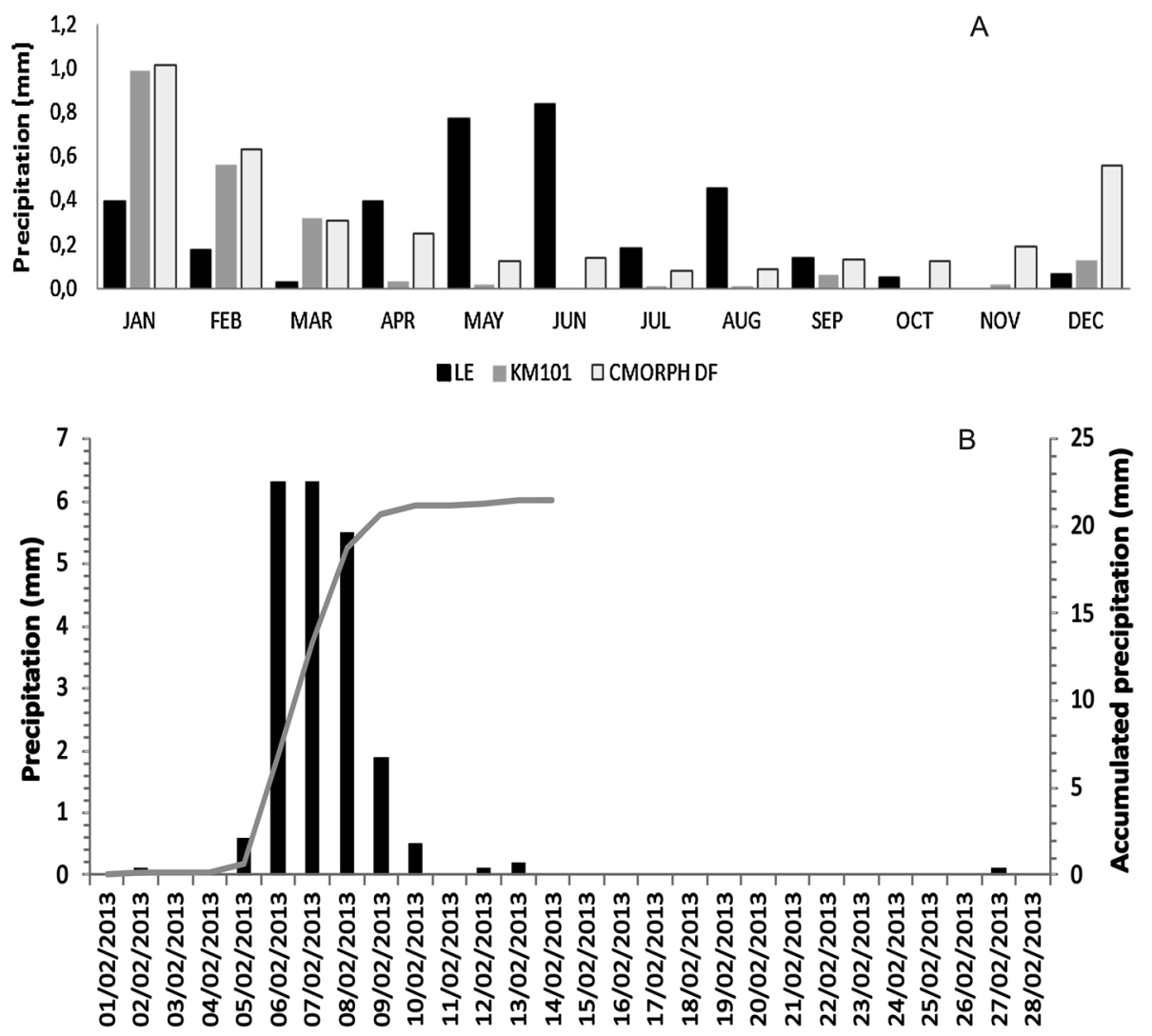

rainfall should play a key role. Previous precipitations were recorded during three last days before the $8 \mathrm{~F}$ event. The accumulated precipitation was $13.2 \mathrm{~mm}$. A comparison of these variables is presented in Table 3 . Wet lines came from westward and rainstorm was intensified by wet lines coming from the northeast; consequently, it is probably that precipitation was intensified in the ANR valley comparing with lower values recorded at the $\mathrm{Km}$ 101 gauge.

\section{Air temperature analysis}

Using the Reanalysis dataset of the NCEP-NCAR, no great temperature variations are found during the occurrence of the $8 \mathrm{~F}$ debris flow. Air temperature anomalies at $500 \mathrm{mb}$ range between 1 and $2{ }^{\circ} \mathrm{C}$ in the $6 \mathrm{~h}$ previous to the $8 \mathrm{~F}$ event. Moreover, there is no clear evidence of increasing in maximum and minimum daily temperature during the three previous days when records from the KM101 and Laguna Embalse gauges are analyzed. Nevertheless, it is important to highlight that higher temperatures were found during January and February; still, they are not in the time window of $8 \mathrm{~F}$ debris flow. On the other hand, the elevation of the isotherm of $0{ }^{\circ} \mathrm{C}$ decreases $483 \mathrm{~m}$ in altitude between the 5th and 8th of February, from 5101 to $4618 \mathrm{~m}$ asl.

\section{Discussion and final remarks}

Dangerous events have been rarely reported in this mountain region of Argentina where an international corridor was established underestimating the potential natural hazard and risk. On February 8, 2013, a sudden event occurred with unsuspected impact for Argentinean authorities and institutions related to communication systems that maintain the international accesses. Due to this 
Table 3 Analysis of precipitation records in local gauges and CMORPH estimation

\begin{tabular}{llllll}
\hline & LE & CMORPH LE & CMORPH DF & Km101 & CMORPH Km101 \\
\hline Precipitation February 8, 2013 (mm) & 0 & 0.7 & $\mathbf{5 . 5}$ & 0 & 2.4 \\
Days with precipitation before the event & 2 & 2 & 3 & 1 & 4 \\
Accumulated precipitation before February 8, 2013 (mm) & 15.5 & 14.3 & 13.2 & 5.40 & 10.4 \\
\hline
\end{tabular}

The bold value indicates the triggering precipitation value of the event $8 \mathrm{~F}$

LE, Laguna Embalse rain gauge; CMORPH LE, satellite estimation at Laguna Embalse; CMORPH DF, satellite estimation at debris flow point; $\mathrm{Km} 101$, rain gauge at $\mathrm{Km} 101$; CMORPH Km101, satellite estimation at Km101

violent event, the international transit was disrupted for a period of 11 days in the Agua Negra Pass. This weird situation provoked 11 families including kids were isolated. A foreign tourist driver tried to overpass the still moving $8 \mathrm{~F}$ debris flow, and he lost the control of the vehicle, and as a consequence, a 10-year-old kid died. However, consequences could be worse considering that over 20 thousand persons crossed from Argentina to Chile along this road during January 2013 prior to this fatal event.

Lacking on historical documentation has favored construction of weak mountain infrastructures in the Andes collapsing during snow storms in cold winter period and due to rainfall-triggered debris flows in the summer period. Even though weather alarms have been systematically implemented for closing international Argentinean passes as prevention in the first cases, their application is absent in the latter. Herein, the natural risk along international corridors increases in the summer period when more persons use to move to Chilean coasts in the holiday season. In the $8 \mathrm{~F}$ debris flow, 50,000 cubic meters of material was removed arriving at the ANR valley with a mean velocity of $35 \mathrm{~km} / \mathrm{h}$ reason resulting in a fatal fortuity accident. Neither, monitoring or alarm systems exist in this mountain area where an international road has been constructed. Moreover, baselines of geomorphological studies considering natural hazards are rare. A first approximation was done by Wolf (2015) in his master thesis. The main focus of recently performed studies concerns about glacier preservation (Schrott 1994, 1996; Leiva 1999; Milana and Maturano 1999; Croce and Milana 2002) being evident the necessity of proving detailed survey of natural hazards.

Still, inventory maps of active geomorphological processes are a good tool for quantify and identify potential hazard (Corominas et al. 2013); they are not enough for understanding natural hazards concerning to volume, frequency, streamflow, sedimentary aspect among others. Lacking on this information disallows the possibility of prediction of events, implementation of non-structure preventive measures, design and construction of proper engineering measures, instrumentation of monitoring equipment, and adaptation of alarm system that alerts about processes occurrence. In this context, to define triggering mechanisms of these natural phenomena is essential as well. Establishing threshold value has been the aim of many studies worldwide (Gabet et al. 2004; Sepúlveda and Padilla 2008; Brunetti et al. 2013). However, this task is very hard in remote mountain areas with scarce gauges. Herein was used an estimation derived by from satellite data $(\mathrm{CMORPH})$ that could be very useful to be implemented in other remote areas. CMORPH technique has been successfully carried out in Mendoza river valley where weather/climate conditions are very similar to our mountain arid study area (Santos et al. 2015).

According to our findings, a low threshold value $(5.5 \mathrm{~mm})$ was estimated by satellite-derived precipitation (CMORPH) for the triggering summer rainfall of $8 \mathrm{~F}$ debris flow. However, this value is above the annual $(0.3 \mathrm{~mm})$ and monthly $(0.6 \mathrm{~mm})$ average. This low precipitation doubly explains saturation of soil/debris that should favor instability and beginning of material movement downslope along the AG basin. Nevertheless, threshold values are completely different in very dry environments as Central Andes with $200 \mathrm{~mm}$ of mean annual precipitation and very steep slopes (Moreiras 2006). Likewise, the role of antecedent precipitation is fundamental. In this work, we could find rainfall at least 3 days previous to event intensified by wet lines coming from northeast. These precipitations are three times the determined triggering value. However, the accuracy of precipitation in the Central Andes is an open issue and more investigation is required.

A combined triggering mechanism was suggested. The initial source area of the $8 \mathrm{~F}$ debris flows is in a permafrost area just above a covered rock glacier coming from Olivares Mount $(6280 \mathrm{~m})$. Thermokarst facies of this glacier evidences a progressive degradation of internal/interstitial glacier ice. This glacial ice degradation could contribute to slope material saturation prior to rainfall during the February 2013. Slope instability associated with permafrost degradation has been referred around the world (Fischer et al. 2006; Huggel 2008). Recently, Molard geoforms have been linked to permafrost collapse (Milana 2015). However, no changes on the $0{ }^{\circ} \mathrm{C}$ isotherm altitude were noted during this period. 
According to this, we consider that it is essential to contemplate multidisciplinary studies to identify the real hazard and risk in mountain areas in the fact climate change scenario. As well, hazards related to temporal natural dams caused by diverse types of landslides should be carefully considered. The primary objective of this paper was to document and study in detail the occurrence of a violent debris flow in the Central Andes trying to warn about the probable catastrophic impact in the future. Herein, we hope these findings could be useful for hazard remediation, mitigation, and prevention plans for the Agua Negra international pass.

Acknowledgements This research work was supported by PIP 112201101-00484 and PIP 11220150100191CO both leader by Moreiras. Natural hazards studies are carried out in the framework of ANLAC (Amenazas Naturales en Los Andes Centrales) Program focus on evaluation of impacts of Natural Hazards of the Central Andes. Results are part of Ph.D. of Vergara at UNRN and master theses of Wolf and Tutzer at Boku University.

\section{References}

Brea JD, Spalletti P, Amores G (2013) The 2006 and 2009 landslide and flood events in the Tartagal River Basin (Argentina). In: Landslide science and practice: risk assessment, management and mitigation. 2nd World Landslide Forum, WLF 2011, Rome, Italy, 3-9 October 2011. Code 104240. 6:341-347

Brunetti MT, Luino F, Vennari C, Peruccacci S, Biddoccu M, Valigi D, Luciani S, Cirio CG, Rossi M, Nigrelli G, Ardizzone F, Di Palma M, Guzzetti F (2013) Rainfall thresholds for possible occurrence of shallow landslides and debris flows in Italy. In: Schneuwly-Bollschweiler M, Stoffel M, Rudolf-Miklau F (eds) Dating torrential processes on fans and cones. Springer, London, pp 327-339

Cannon SH, Ellen SD (1985) Rainfall conditions for abundant debris avalanches, San Francisco Bay region, California. Calif Geol 38(12):267-272

Chen S, Hong Y, Cao Q, Kirstetter PE, Gourley JJ, Qi Youcun, Zhang Jian, Howard K, Hub J, Wang J (2013) Performance evaluation of radar and satellite rainfalls for Typhoon Morakot over Taiwan: are remote-sensing products ready for gauge denial scenario of extreme events? J Hydrol 506:4-13

Coe JA, Michael JA, Crovelli RA, Savage WZ, Laprade WT, Nashem WT (2004) Probabilistic assessment of precipitation-triggered landslides using historical records of landslide occurrence, Seattle, Washington. Environ Eng Geosci 2:103-122

Corominas J, Van Westen C, Frattini P, Cascini L, Malet JP, Fotopoulou S, Catani F, Van Den Eeckhaut M, Mavrouli O, Agliardi F, Pitilakis K, Winter MG, Pastor M, Ferlisi S, Tofani V, Hervas J, Smith JT (2013) Recommendations for the quantitative analysis of landslide risk. Bull Eng Geol Environ. doi:10.1007/s10064-013-0538-8

Croce FA, Milana JP (2002) Internal structure and behavior of a rock glacier in the arid Andes of Argentina. Permafrost Periglac Process 13(4):289-299

Crosta GB, Frattini P (2003) Distributed modeling of shallow landslides triggered by intense rainfall. Nat Hazards Earth Syst Sci 3:81-93

D’Odorico P, Fagherazzi S, Rigon R (2005) Potential for landsliding: dependence on hyetograph characteristics. J Geophys Res 110:F01007. doi:10.1029/2004JF000127
Esper Angillieri MY (2011) Inventario de procesos de remoción en masa de un sector del departamento Iglesia, San Juan. Revista de la Asociación Geológica Argentina 68(2):225-232

Kjelstad KJF (2011) Regional rainfall thresholds using global high resolution satellite precipitation estimates. A case study of landslides in Bangladesh. Master thesis, Faculty of Mathematics and Natural Sciences, University of Oslo. http://www.duo.uio.no

Fischer L, Kaab A, Huggel C, Noetzli J (2006) Geology, glacier retreat and permafrost degradation as controlling factors of slope instabilities in a high-mountain rock wall: the Monte Rosa east face. Nat Hazards Earth Syst Sci 6:761-772

Frattini P, Crosta GB, Fusi N, Negro PD (2004) Shallow landslides in pyroclastic soil: a distributed modeling approach for hazard assessment. Eng Geol 73:277-295

Gabet EJ, Burbank DW, Putkonen JK, Pratt-Sitaula BA, Ojhac T (2004) Rainfall thresholds for landsliding in the Himalayas of Nepal. Geomorphology 63:131-143

Glade T (2000) Modelling landslide-triggering rainfalls in different regions of New Zealand-the soil water status model. Geomorphol NE 122:63-84

Govi M, Mortara G, Sorzana P (1985) Eventi idrologici e frane. Geol Appl Idrogeol 20(2):395-401

Guzzetti F, Peruccacci S, Rossi M, Stark CP (2007) Rainfall thresholds for the initiation of landslides in central and southern Europe. Meteorol Atmos Phys 98:239-267

Guzzetti F, Peruccacci S, Rossi M, Stark CP (2008) The rainfall intensity-duration control of shallow landslides and debris flows: an update. Landslides 5(1):3-17

Heredia N, Rodriguez Fernandez LR, Gallastegui G, Buisquets P, Colombo F (2002) Geological setting of Argentine Frontal Cordillera in the flat-slab segment $\left(30^{\circ} 00^{\prime}-31^{\circ} 30^{\prime} \mathrm{S}\right.$ latitude). J S Am Earth Sci 15:79-99

Hirpa FA, Gebremichael M, Hopson T (2010) Evaluation of highresolution satellite precipitation products over very complex terrain in Ethiopia. J Appl Meteorol Climatol. doi:10.1175/ 2009JAMC2298.1

Huggel C (2008) Recent extreme slope failures in glacial environments: effects of thermal perturbation. Quat Sci Rev 30:1-12

Hungr O (2005) Classification and terminology. In: Jakob M, Hungr $\mathrm{O}$ (eds) Debris-flow hazards and related phenomena, praxis. Springer, Berlin

Iverson RM (2000) Landslide triggering by rain infiltration. Water Resour Res 36:1897-1910

Jibson RW (1989) Debris flow in southern Porto Rico. In: Schultz, Jibson (eds) Landslide processes of the eastern United States and Puerto Rico. Geological Society of American Special Paper 236:29-55

Johnson AM, Rodine JR (1984) Debris flow. In: Brundsen D, Prior DB (eds) Slope instability. Wiley, Hoboken, p 620

Joyce RJ, Janowiak JE, Arkin PA, Xie P (2004) CMORPH: a method that produces global precipitation estimates from passive microwave and infrared data at high spatial and temporal resolution. J Hydromet 5:487-503

Kalnay E et al (1996) The NCEP/NCAR 40-year reanalysis project. Bull Am Meteorol Soc 77:437-471

Keim RF, Skaugset AE (2003) Modelling effects of forest canopies on slope stability. Hydrol Processes 17:1457-1467

Lan HX, Lee CF, Zhou CH, Martin CD (2005) Dynamic characteristics analysis of shallow landslides in response to rainfall event using GIS. Environ Geol 47:254-267

Leiva JC (1999) Recent fluctuations of the Argentinean glaciers. Glob Planet Change 22(1-4):169-177

Marcato G, Bossi G, Rivelli F, Borgatti L (2012) Debris flood hazard documentation and mitigation on the Tilcara alluvial fan (Quebrada de Humahuaca, Jujuy province, North-West Argentina). Nat Hazards Earth Syst Sci 12(6):1873-1882 
Milana JP (2015) Molards and their relation to landslides involving permafrost failure. Permafr Periglac Process. doi:10.1002/ppp. 1878

Milana JP, Maturano A (1999) Application of radio echo sounding at the arid Andes of Argentina: the Agua Negra Glacier. Glob Planet Change 22(1-4):179-191. doi:10.1016/S09218181(99)00035-1

Minetti JL, Barbieri P, Poblete AG y Sierra E (1986) El Régimen de precipitaciones de la provincia de San Juan y su entorno. Informe Técnico Nro. 8 CIRSAJ, CONICET, IPG-HOEA, p 200

Moreiras SM (2005) Climatic effect of ENSO associated with landslide occurrence in the Central Andes, Mendoza province,Argentina. Landslides 2(1):53-59

Moreiras SM (2006) Frequency of debris flows and rockfall along the Mendoza river valley (Central Andes), Argentina. Quat Int 158:110-121

Moreiras SM (2009) Análisis estadístico probabilístico de las variables que condicionan la inestabilidad de las laderas en los valles de los ríos Las Cuevas y Mendoza. Revista de la Asociación Geológica Argentina 65(4):780-790

Moreiras SM, Sepúlveda SA (2013) The high social and economic impact 2013 summer debris flow events in central Chile and Argentina. Bollettino di Geofisica Teorica ed Applicat 54(2):181-184

Polanski J (1978) El Carbonífero y Pérmico de la Argentina, Sec edn. Eudeba, Buenos Aires, p 216

Santos JR, Norte F, Moreiras SM, Araneo D, Simonelli S (2015) Predicción de episodios de precipitación que ocasionan aludes en el área montañosa del noroeste de la Provincia de Mendoza, Argentina (Precipitation events prediction that causes debris flow and landslides over mountainous area on norwest region of Mendoza province, Argentina). GEOACTA 40(1):65-75

Schaefer JT (1990) The critical success index as an indicator of warning skill. Weather Forecast 5:570-575. doi:10.1175/15200434(1990)005<0570:tcsiaa >2.0.co;2
Schrott L (1994) Solar radiation as a controlling factor in a subtropical, semi arid high Andes geological system-Agua Negra, San Juan. Argentina Heidelberger Geographische Arbeiten 94:199

Schrott L (1996) Some geomorphological-hydrological aspects of rock glaciers in the Andes (San Juan, Argentina). Zeitschrift fur Geomorphologie 104:161-173

SEGEMAR (2000) Hoja Geológica Rodeo (preliminar). Buenos Aires (Unpublished)

Sepúlveda SA, Padilla C (2008) Rain-induced debris and mud flow triggering factors assessment in the Santiago Cordilleran foothills, Central Chile. Nat Hazards 47:201-215

Sepúlveda SA, Rebolledo S, Vargas G (2006) Recent catastrophic debris flows in Chile: geological hazard. Climatic relationships and human response. Quat Int 158:83-95

Sepúlveda SA, Moreiras SM, Lara M, Alfaro A (2015) Debris flows in the Andean ranges of central Chile and Argentina triggered by 2013 summer storms: characteristics and consequences. Landslides 12(1):115-133. doi:10.1007/s10346-014-0539-0

Su F, Hong Y, Lettenmaier DP (2008) Evaluation of TRMM Multisatellite Precipitation Analysis (TMPA) and its utility in hydrologic prediction in the La Plata Basin. J Hydrometeorol. doi:10.1175/2007JHM944.1

Varnes DJ (1978) Slope movement types and processes. In: Schuster RL, Krizek RJ (eds) Landslides: analysis and control, transportation research. Board National Academy of Sciences, Washington

Wieczorek GF, Morgan BA, Campbell RH (2000) Debris flow hazards in the Blue Bridge of central Virginia. Environ Eng Geosci 1(1):11-27

Wolf J (2015) Geomorphological evidence of former glaciations and recent permafrost distribution at the Paso de Agua Negra, Argentina. Master thesis, University of Natural Resources and Life Sciences, Vienna, Austria

WP/WLI (1993) Multilingual landslide glossary. Bitech Publishers, Richmond, p 59 